\title{
Strategic alignment maturity criteria as a catalyst for enhancing operational excellence in Jorda- nian industrial companies
}

\author{
Adel AL-Hashem ${ }^{*}$ and Tareq Abu Orabi ${ }^{a}$
}

${ }^{a}$ Management Information Systems Department, Al- Balqa Applied University, Salt, 19117, Jordan

\section{H R O N I C L E}

\section{Article history:}

Received: August 10, 2020

Received in revised format:

November 152020

Accepted: November 27, 2020

Available online:

December 1, 2020

\section{Keywords:}

Business and IT strategy

Strategic alignment maturity crite-

ria

Operational excellence

\section{A B S T R A C T}

High convergence level of strategic alignment between business and information technology helps companies enhance operational excellence. This research aims to identify strategic alignment maturity criteria level and their impacts on operational excellence in Jordanian industrial companies. The population of the study consists of all managers at top and middle management and a purposive sample is used to answer questionnaire items. In this survey, 288 valid responses are collected for analysis using SPSS (20) and smart PLS "V. 3". The study reveals that there is a significantly positive impact of strategic alignment maturity criteria (communication, competency-value Measurement, governance, partnership, scope \& architecture and skills) on operational excellence. The most maturity criteria have a mid-level of maturity except scope \& architecture and competency-value measurement criteria which maintain a low level. Thus, the study concluded that the researched companies have to recognize the business value of information technology (IT) investment and harmonizing IT architecture with business structure.

\section{Introduction}

Business firms continuously seek to find new business models to achieve operational excellence and differentiate themselves from others. Strategic alignment maturity between business and information technology has been recognized as a business model to avoid the failure of information technology investments to improve institutional performance and, in particular, the operational excellence (Henderson \& Venkatraman, 1993). In contrast, misalignment between business and information technology can lead to several problems that prevent the return of investment of information technology in the light of turbulent business environment (Papp, 2001). The key problem in this study stems from the lack of cooperation between business and information technology executives during strategic planning process, and IT department staff who are not knowledgeable about business departments and vice versa. Therefore, the fast-changing in the business environment leverages the gap between business and IT external domains (scope, governance and competencies) and internal domains (structure, skills and processes). The strategic alignment between business and information technology is a difficult task (Peppard \& Campbell, 2014). Therefore, Operational Excellence may be achieved when information technology, business process and employees' skills are aligned to increase productivity growth and decreased operational costs (Schneider, 2003). For this reason, business firms seek not only to survive in the market place but also to gain sustainable competitive advantage by achieving operational excellence (Jovane et al., 2008). There are only a few empirical studies investigated strategic alignment maturity criteria as separated constructs with operational excellence as a dependent construct. This study aims to explore the relationship between strategic alignment maturity criteria (communication, competency-value Measurement, governance, partnership, scope \& architecture and skills) and operational excellence in the industrial companies in Jordan which are considered the backbone of

* Corresponding author.

E-mail address: adelalhashm@bau.edu.jo (A. AL-Hashem) 
the economy. The study purpose is to answer some questions that can be empirically examined in researched companies in Jordan comparing with developing countries as attempt to address the gaps between them according the following questions: what is the level of strategic alignment maturity criteria? what is the level of operational excellence in Jordanian industrial companies.

\section{Business and IT Strategy}

Business strategy is considered as a tool which enables business managers to be more proactive and support the control process over their own activities for business success (Maduenyi et al., 2015; Lewis., 2008). The business strategy is defined as longterm goals and the objectives required the allocation of business resources and the adoption of courses of action to be achieved (Parnell, et al., 2012). Armstrong and Barron (2002) defined business strategy as making decisions in business to achieve the predetermined goal or objective. According to Porter and Kramer, (2002), information technology strategy plays an essential role in any business success, and business executives are continuously enhancing the effective use of information technology to gain sustainable competitive advantage; in recent competitiveness, the information technology is considered as a backbone for any business firm. Thus, the information technology strategy refers to the overall plan, which includes objectives and tactics that support the efficient utilization within a business firm, the business strategy and information technology strategy has to be aligned (Floyd \& Wolf, 2010; Henderson \& Venkatraman,1993).

\subsection{Strategic Alignment Maturity Criteria}

The strategic alignment between business and information technology is achieved when business strategy objectives are enabled by effective use of information technology strategy, the fact of integration between business units and IT unit became the business priority for both public and private executive managers (Luftman et al., 1993). The concept of business-IT alignment is used in the prior studies in various terms interchangeably as harmonization (Luftman et al., 1993), bridge, fit (Venkatraman, 1989), integration (Weill \& Broadbent, 1998), alignment, linkage (Henderson \& Venkatraman, 1993), fusion (Smaczny, 2001). Strategic alignment maturity model enables to evaluate the maturity level between business and information technology based on gender criteria (communication, competency-value Measurement, governance, partnership, scope \& architecture, and skills). The convergence mechanisms between these criteria are essential to achieve a high level of maturity between business and IT units (Luftman, 2000). According to Luftman (2000), the business-IT alignment refers to using information technology in a timely and appropriate way, in harmony with business strategies, needs, and goals. The strategic alignment maturity between business and IT strategies became a fundamental task when business firms trying to reach a high level of convergence; they should evaluate the level of a strategic alignment maturity level to determine the weak points and enhance the specific criterion to maximize the overall maturity level (Symons, 2005). Thus, Strategic integration is a continuous approach of improvements that affects the maturity criteria for both information technology and business sides and the business firms have to be able to align their competitive position with the external and internal business environment. According to Luftman (2000), the strategic alignment maturity model includes five levels of maturity: The first level is the initial/ad hoc Process, which means information technology strategies are not fit together. The second level is a committed to process refers to the business has committed to harmonized. The third level is the established focused process which refers to the maturity of business and information technology strategies formulated and concentrated on business goals and objectives. The fourth level is an improved-managed process which means that the information technology is a value Centre. The fifthlevels is Optimized Process, which refers to the aligned and co-adaptive strategic planning of business and information technology. In addition, there are six criteria of strategic alignment maturity addressed to measure the strategic alignment maturity between business and information technology within an organization, as shown in Table 1 as follow: (1) Communications Maturity criterion to ensure the effectiveness of knowledge sharing across business firms. (2) Competency-Value Measurement Maturity criterion means the value of information technology in terms of contribution to the business units.(3) Governance Maturity criterion refers to business and information technology participants formally determining the priorities and allocating information technology assets.(4) Partnership Maturity criterion means that how the business firms perceive the other's contribution, the trust among participants, and the sharing of the rewards and risks.(5) Scope \& Architecture Maturity criterion refers to How information technology directly impacts the strategic partners and customers and evaluates and uses emerging technology effectively and provides solutions according to the customers' requirements.(6) Skills Maturity criterion means that the human resources issues such as skills and training, performance, salary and career opportunity are evaluated to develop the business environment and its culture. The evidence was introduced by Jerry Luftman et al. (2008) that most organizations reached the level two and three of strategic alignment maturity in terms a low and middle level of maturity. Also, several studies stated that strategic alignment maturity has a positive impact on operational efficiency, competitive advantage, overall performance and innovativeness; (Wagner, 2014; Kalkan et al., 2011; Luftman, 2000, Henderson \& Venkatraman, 1999). Based on the following hypotheses have been introduced:

\footnotetext{
$\mathrm{H}_{1}$ : Communication has significantly positive impact on operational excellence.

$\mathrm{H}_{2}$ : Competency and value measurement have significantly positive impacts on operational excellence.

$\mathrm{H}_{3}$ : Governance has a significantly positive impact on operational excellence.

$\mathrm{H}_{4}$ : Partnership has a significantly positive impact on operational excellence.

$\mathrm{H}_{5}$ : Scope and architecture have significantly positive impacts on operational excellence.
} 
$\mathrm{H}_{6}$ : Skills have significantly positive impacts on operational excellence.

Table 1

Strategic Alignment Maturity Criteria Dimensions

\begin{tabular}{llll}
\hline Variable & Dimensions & & Reference \\
\hline Strategic Alignment Maturity criteria & $\bullet$ & Communications & Luftman $(2000)$ \\
& $\bullet$ & Competency-Value Measurement \\
& $\bullet \quad$ Governance \\
& $\bullet \quad$ Partnership \\
& $\bullet \quad$ Scope \& Architecture \\
\hline
\end{tabular}

\section{Operational Excellence}

Operational excellence refers to the continuity of production and delivery system excellence to provide valued products and services (Van Assen, 2011). Russell and Koch (2009) mentioned that operational excellence is reaching the highest level of efficiency by doing tasks cheaper, better, and faster. Operational excellence enables companies to re-engineer existing operation methods to achieve productivity and profitability (Eriksson et al., 2012). Operational excellence refers to making continuous improvements in the productivity, delivery of items and services and quality (Cesarotti \& Spada, 2009). Nowadays, operational excellence is considered a prerequisite to business for maximizing the operational performance and being competitive (Wahab, 2016). Porter (2005) stated that business could only gain a competitive advantage if the business pursues a dedicated positioning strategy. Hence, operational excellence is a particular type of cost-management. In addition, the functional area integration is a crucial factor for successful management to achieve operational excellence (Waruhiu, 2014). To achieve operational excellence business firms should link the strategic goals with operational activities (Russell, 2009). According to Decker (2005), a continuous process of steps includes the internal needs of the business, integrating with business practices, and finding new ways of doing things. The three steps model introduced by Cognizant (2011) involves production and control planning, implementation, and work effectiveness assessment to make continuous improvements. Thus, business can achieve operational excellence through continuous improvements in the operation processes (Ojha, 2015). Based on the prior studies, the operational excellence practices are adopted by business to gain a competitive advantage by using effective and efficient assets and qualified people to introduce high quality of products and services (Al Haraisa, 2017). Table 2 clarifies the dimensions of operational excellence as follow in Table 2:

Table 2

Operational Excellence Dimensions

\begin{tabular}{lll}
\hline Variable & Dimensions & Author \\
\hline Operational Excellence & 1-Cost Management. 2-Product Differentiation. & Serfontein, (2010) \\
& 3- Integration. & \\
1- high efficiency and effectiveness. 2- customer & (Lu et al., 2011) \\
& and market oriented. 3- focus on the right first & \\
& time. & \\
1.World-class performance. & Năftănăilă, and Cioana, (2013) \\
& \\
2. process focus. & \\
\hline
\end{tabular}

\section{Measurement Scales Development}

Based on the previous studies, a survey was built as an independent constructs (Communications (C), Competency-Value Measurement (CMV), Governance (G), Partnership (P), Scope \& Architecture and Skills(S\&A)) which depends on the strategic aliment maturity criteria management introduced by Luftman (2000) and the dependent construct operational excellence(OP) is based on studies of Serfontein, (2010), Lu et al. (2011). This model concentrates on measuring the level and the impact of each criterion of strategic alignment maturity as a separate construct on dependent construct operation excellence and determines the strategic alignment maturity level between business and information technology.

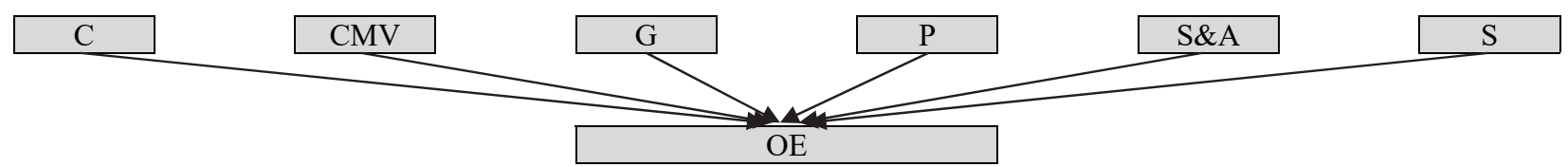

Fig. 1. The conceptual Model

\section{Research Methodology}

To examine the research hypotheses and questions, a quantitative approach was used to determine the level of strategic alignment maturity between business and information technology and the strategic alignment maturity criteria' impact as a separate construct on operational excellence. The study population consisted of the top management and middle management from (76) industrial companies listed in the stock change in Jordan. A purposive sample of (288) managers was chosen from (63) companies. A designed questionnaire consisted of (24) items to measure strategic alignment maturity criteria is based on the 
previous study of Luftman (2000), then (6) items to measure the operational excellence is adopted from Lu et al. (2011). A pilot study was employed to refine the questionnaire items. The Likert scale was used, where $1=$ strongly disagree, $2=$ disagree, 3=neutral, 4= agree, 5=strongly agree. The research data were analyzed using SPSS (20) and smart PLS "V. 3".

\section{Data Analysis and Hypotheses Testing}

\subsection{Multicollinearity}

To test the internal reliability and validity of the measurement model, several statistical approaches were used to proceed with the structural model analysis. The first step was to utilize variance inflation factor (VIF) to examine the validity of the six independent constructs and potential collinearity among independent constructs (Communications, Competency-Value Measurement, Governance, Partnership, Scope \& Architecture and Skills). According to Hair et al. (2011) if the VIF value is 5 and higher it indicates that there are collinearity problems. Hence, all Variance inflation factor (VIF) values for independent constructs are less than (5) as follows in Table 3:

Table 3

Multicollinearity Statistics

\begin{tabular}{|c|c|c|c|c|c|c|c|c|c|c|c|}
\hline \multicolumn{2}{|c|}{ Communications } & \multicolumn{2}{|c|}{$\begin{array}{l}\text { Competency-Value } \\
\text { Measurement }\end{array}$} & \multicolumn{2}{|c|}{ Governance } & \multicolumn{2}{|c|}{ Partnership } & \multicolumn{2}{|c|}{ Scope \& Architecture } & \multicolumn{2}{|l|}{ Skills } \\
\hline Indicator & VIF & Indicator & VIF & Indicator & VIF & Indicator & VIF & Indicator & VIF & Indicator & VIF \\
\hline $\mathrm{C} 1$ & 1.547 & CVM1 & 1.248 & G1 & 1.325 & P1 & 1.551 & S\&A1 & 1.528 & $\mathrm{~S} 1$ & 1.465 \\
\hline $\mathrm{C} 2$ & 1.841 & CVM2 & 1.613 & G2 & 1.658 & $\mathrm{P} 2$ & 1.459 & S\&A2 & 1.481 & $\mathrm{~S} 2$ & 1.417 \\
\hline C3 & 1.558 & CVM3 & 1.741 & G3 & 1.357 & P3 & 1.881 & S\&A3 & 1.761 & $\mathrm{~S} 3$ & 1.351 \\
\hline C4 & 1.389 & CVM4 & 1.622 & G4 & 1.448 & P4 & 1.384 & S\&A4 & 1.378 & S4 & 1.497 \\
\hline
\end{tabular}

\subsection{Convergent Validity and Reliability}

Table 4

Convergent Validity and reliability values

\begin{tabular}{|c|c|c|c|c|c|}
\hline Construct & Item & Loading & Cronbach's alpha & CR & AVE \\
\hline \multirow[t]{4}{*}{ Communications } & $\mathrm{Cl}$ & 0.952 & \multirow[t]{4}{*}{0.939} & \multirow[t]{4}{*}{0.942} & \multirow[t]{4}{*}{0.925} \\
\hline & $\mathrm{C} 2$ & 0.961 & & & \\
\hline & $\mathrm{C} 3$ & 0.893 & & & \\
\hline & $\mathrm{C} 4$ & 0.992 & & & \\
\hline \multirow[t]{4}{*}{ Competency-Value Measurement } & CVM1 & 0.878 & \multirow[t]{4}{*}{0.873} & \multirow[t]{4}{*}{0.902} & \multirow[t]{4}{*}{0.866} \\
\hline & CVM2 & 0.865 & & & \\
\hline & CVM3 & 0.933 & & & \\
\hline & CVM4 & 0.978 & & & \\
\hline \multirow[t]{4}{*}{ Governance } & G1 & 0.878 & \multirow[t]{4}{*}{0.852} & \multirow[t]{4}{*}{0.869} & \multirow[t]{4}{*}{0.848} \\
\hline & G2 & 0.971 & & & \\
\hline & G3 & 0.859 & & & \\
\hline & G4 & 0.813 & & & \\
\hline \multirow[t]{4}{*}{ Partnership } & P1 & 0.878 & \multirow[t]{4}{*}{0.865} & \multirow[t]{4}{*}{0.889} & \multirow[t]{4}{*}{0.857} \\
\hline & $\mathrm{P} 2$ & 0.911 & & & \\
\hline & P3 & 0.858 & & & \\
\hline & $\mathrm{P} 4$ & 0.817 & & & \\
\hline \multirow[t]{4}{*}{ Scope \& Architecture } & S\&A1 & 0.838 & \multirow[t]{4}{*}{0.821} & \multirow[t]{4}{*}{0.841} & \multirow[t]{4}{*}{0.829} \\
\hline & S\&A2 & 0.951 & & & \\
\hline & S\&A3 & 0.829 & & & \\
\hline & S\&A4 & 0.816 & & & \\
\hline \multirow[t]{4}{*}{ Skills } & $\mathrm{S} 1$ & 0.899 & \multirow[t]{4}{*}{0.889} & \multirow[t]{4}{*}{0.911} & \multirow[t]{4}{*}{0.885} \\
\hline & $\mathrm{S} 2$ & 0.922 & & & \\
\hline & S3 & 0.931 & & & \\
\hline & $\mathrm{S} 4$ & 0.816 & & & \\
\hline \multirow[t]{6}{*}{ Operational Excellence } & OE1 & 0.901 & \multirow[t]{6}{*}{0.913} & \multirow[t]{6}{*}{0.927} & \multirow[t]{6}{*}{0.905} \\
\hline & OE2 & 0.913 & & & \\
\hline & OE3 & 0.998 & & & \\
\hline & OE4 & 0.905 & & & \\
\hline & OE5 & 0.965 & & & \\
\hline & OE6 & 0.981 & & & \\
\hline
\end{tabular}

The convergent validity and reliability analysis are used to confirm internal consistency and the findings in Table 4 show the average variance extracted (AVA) values for strategic alignment maturity criteria, communication value was $(0.925)$, competency -value measurement (0.866), governance (0.848), partnership (0.857), scope and architecture (0.829), skills (0.885) and the dependent variable operational excellence value was (0.905). Hence, all research constructs were above 0.50 that indicate satisfactory values. To demonstrate composite reliability, the (CR) values were ranged as a follow communication value was (0.942), competency -value measurement (0.902), governance (0.869), partnership (0.889), scope and architecture (0.841), skills $(0.911)$ and the dependent variable operational excellence value was $(0.927)$. The findings confirmed that the average 
variance extracted (AVE) values for all constructs and Cronbach's alpha values are all above 0.70. Hence results were satisfactory which means the internal consistency among items were confirmed for each construct.AS shown in Table 4, the items loading were above (0.708).

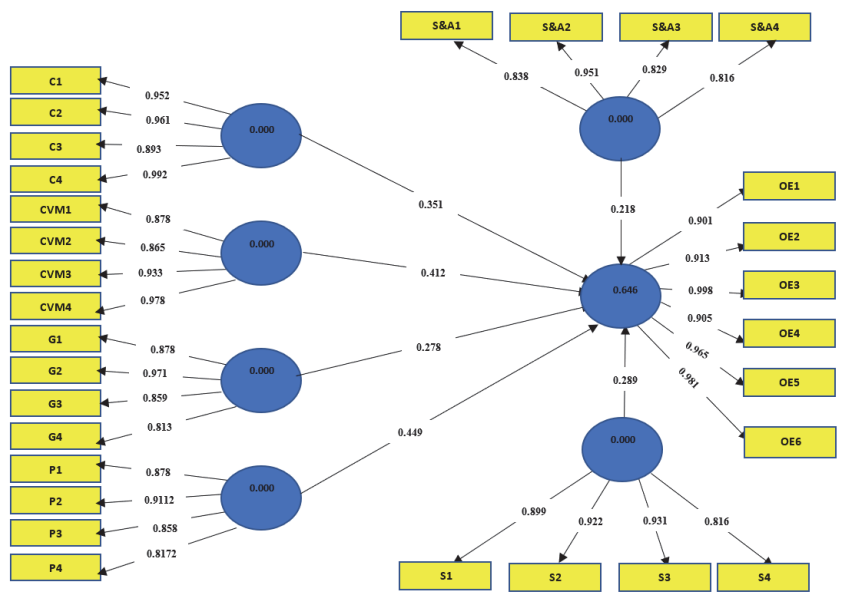

Fig. 2. Measurement Model

\subsection{Study Constructs Description}

Table 5 illustrates the descriptive statistics for research constructs, the mean values for all independent constructs were ranged as a follow: Competency-value measurement Criterion (2.86), scope \& architecture criterion (2.92), communications criterion (3.52), governance criterion (3.55), skills criterion (3.64) and partnership criterion (3.76), which means independent constructs ranged from low to middle level as shown in table (3), therefore, the maturity level of strategic alignment criteria was (3.68). Dependent construct operational excellence has a middle level (3.48).

Table 5

Constructs Description

\begin{tabular}{|c|c|c|c|}
\hline NO & Question & Mean & level \\
\hline $\mathrm{C} 1$ & Information technology staff understand business functions. & 3.71 & Mid \\
\hline $\mathrm{C} 2$ & Business employees understand technical logic. & 3.58 & Mid \\
\hline $\mathrm{C} 3$ & Top management supports the interaction between business and IT units. & 3.32 & Mid \\
\hline $\mathrm{C} 4$ & Business unit in touch with the IT unit to solve problems. & 3.47 & Mid \\
\hline \multicolumn{2}{|c|}{ Communications Criterion Average } & 3.52 & Mid \\
\hline CMV1 & IT investments are measured continuously. & 3.21 & Mid \\
\hline CMV2 & The business value is measured continuously. & 2.76 & Low \\
\hline CMV3 & Service provided by IT unit to business unit measured continuously. & 2.65 & Low \\
\hline CMV4 & Top management improves IT competencies continuously. & 2.82 & Low \\
\hline \multicolumn{2}{|c|}{ Competency-Value Measurement Criterion Average } & 2.86 & Low \\
\hline G1 & IT management is involved in the strategic planning process. & 3.22 & Mid \\
\hline G2 & Business units involved in IT strategy formalization. & 3.58 & Mid \\
\hline G3 & IT project prioritized effectively. & 3.77 & Mid \\
\hline G4 & Business value evaluation was conducted by committees formalized for this purpose. & 3.63 & Mid \\
\hline \multicolumn{2}{|c|}{ Governance Criterion Average } & 3.55 & Mid \\
\hline P1 & Top management recognized IT value. & 3.84 & Mid \\
\hline $\mathrm{P} 2$ & Chief information officer involved in managing IT projects. & 3.92 & Mid \\
\hline P3 & The responsibility is shared between business and IT units. & 3.53 & Mid \\
\hline P4 & The relationship between business and IT depends on trust. & 3.76 & Mid \\
\hline \multicolumn{2}{|c|}{ Partnership Criterion Average } & 3.76 & Mid \\
\hline S\&A1 & Business transformation is based on environmental changes. & 3.24 & Mid \\
\hline S\&A2 & There is a harmonization between business structure and IT architecture. & 2.82 & Low \\
\hline S\&A3 & IT management evaluates advanced IT impact on business continuity. & 2.69 & Low \\
\hline S\&A4 & Information systems have the ability to respond to internal and external changes. & 3.17 & Mid \\
\hline \multicolumn{2}{|c|}{ Scope \& Architecture Criterion Average } & 2.92 & Low \\
\hline S1 & There is an opportunity for IT staff to make the rotation. & 3.58 & Mid \\
\hline S2 & There are employee training and education programs continuously. & 3.72 & Mid \\
\hline S3 & IT staff skills consistency of business employees skills. & 3.69 & Mid \\
\hline S4 & Top management supports IT innovations. & 3.57 & Mid \\
\hline \multicolumn{2}{|c|}{ Skills Criterion Average } & 3.64 & Mid \\
\hline OP1 & The company reduces the defect rate in manufacturing processes continuously & 3.61 & Mid \\
\hline OP2 & The company reduces lead time and complexity continuously. & 3.44 & Mid \\
\hline OP3 & The company reduces the operational costs continuously. & 3.82 & Mid \\
\hline OP4 & There is an operational strategy to respond to the competitors. & 3.41 & Mid \\
\hline OP5 & The company has profitability compared with competitors. & 3.17 & Mid \\
\hline OP6 & The company responds to market needs quickly. & 3.46 & Mid \\
\hline \multicolumn{2}{|c|}{ Operational Excellence Average } & 3.48 & Mid \\
\hline
\end{tabular}


To examine the research model, PLS was utilized to test research hypotheses; as shown in Table 6, there is a significant impact of communication criteria communication, competency-value Measurement, governance, partnership, scope $\&$ architecture, and skills) on operational excellence (path coefficient values were significant which were $>2$ and $\mathrm{P}$-value $<=0.05$ ). Hence, $\mathrm{H} 1$ was confirmed. In addition, the H2, H3, H4, H5, and H6 were confirmed based on the results, as shown in Table 6 below.

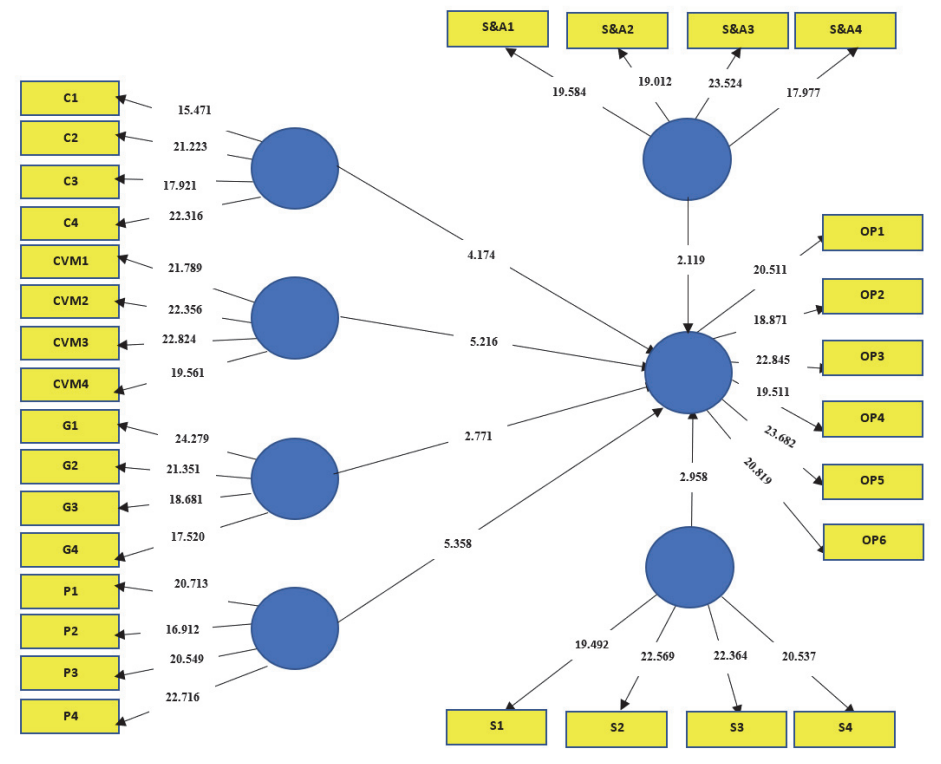

Fig. 3. Structural Model

Table 6

Hypotheses testing

\begin{tabular}{lllll}
\hline Hypothesis & t. Value & P. Value & Path Coefficient & Finding \\
\hline $\mathrm{C} \rightarrow$ OP & 4.174 & 0.009 & $0.351^{* *}$ & Confirmed \\
$\mathrm{CVM} \rightarrow \mathrm{OP}$ & 5.216 & 0.001 & $0.412^{* *}$ & Confirmed \\
$\mathrm{G} \rightarrow \mathrm{OP}$ & 2.771 & 0.021 & $0.278^{* *}$ & Confirmed \\
$\mathrm{P} \rightarrow \mathrm{OP}$ & 5.358 & 0.000 & $0.449^{* *}$ & Confirmed \\
$\mathrm{S} \& \mathrm{~A} \rightarrow \mathrm{OP}$ & 2.119 & 0.029 & $0.218^{* *}$ & Confirmed \\
$\mathrm{S} \rightarrow \mathrm{OP}$ & 2.958 & 0.017 & $0.289^{* *}$ & Confirmed \\
\hline
\end{tabular}

\section{Findings and Discussion}

The study's findings empirically confirmed the relationship between strategic alignment maturity criteria and operational excellence in the Jordanian industrial companies. This can illustrate the impact of strategic alignment maturity criteria (communication, Competency-Value Measurement, Governance, Partnership, Scope \& Architecture, and Skills criterion) on the dependent construct operational excellence. Based on the prior studies that stated by Wagner (2014), Kalkan et al. (2011), Luftman (2000), Henderson and Venkatraman (1999), strategic alignment maturity criteria have positive impacts on operational efficiency, competitive advantage, overall performance, and innovativeness. Thus, there was consistency between the study results and the previous studies, Therefore, Operational Excellence may be achieved when information technology, business process and employees' skills are aligned to increase productivity growth and decreased operational costs (Schneider, 2003). According to the strategic alignment maturity criteria level, the communications construct was in the middle level, which means the researched companies are still immature and need to exploit new mechanisms and technologies that support the knowledge-sharing process between business units and information technology units to maximize communication level as a catalyst for operational excellence. The competency-value measurement level was at a low level, which means that the researched companies cannot utilize business value measurements and improve business competencies continuously that might affect the operational excellence process. Governance criterion was at the middle level, which indicates that the IT management was involved in the strategic planning process. Partnership criterion was at the middle level, which indicates that the responsibility between business and information technology has been shared simultaneously as companies have to leverage the good criteria. In addition, the scope \& architecture criterion was at a low level, which indicates that the researched companies don't have the ability to respond to internal and external changes in the environment and depend on the traditional 
ways to develop manufacturing processes. Also, there is no harmonization between business structure and Information technology structure. Finally, the skills criteria have a good level of education and training of employees in the business and information technology departments, which means a good level of convergence between employee's skills in different units with information technology staff. Hence, the research findings indicated good levels of application of strategic alignment maturity criteria as a whole and operational excellence. The results of this study correspond with prior studies of Jerry Luftma (et al,2008), most organizations obtained strategic alignment maturity level two and level three. The second level is the committed to process refers to the business has committed to harmonized. The third level is the established focused process refers to the maturity of business and information technology strategies formulated and concentrated on business goals and objectives. in term of strategic alignment maturity in Jordanian industrial companies still immature.

\section{Conclusions, Limitations and Future works}

Therefore, the study concluded that there is a significantly positive impact of strategic alignment maturity between business and information technology on operational excellence. Thus, business firms should be improving the maturity criteria to high level continuously to sustain itself and gain competitive advantage in the turbulent changes in the environment, in this context the use of innovative models and advanced technology become essential to bridge the convergence gap for each criteria between business units and information technology unit. By reviewing the literature in this domain, this study contributed to add more theoretical and empirical evidence of the impact of the independent constructs separately (communication, Competency-Value Measurement, Governance, Partnership, Scope \& Architecture and Skills criterion) on dependent construct operational excellence in specific. Hence, the reaching high convergence level of strategic alignment between business and information technology can help companies enhance operational excellence. Finally, this study conducted in the corona-virus (COVID-19) period which leads to several problems related to questionnaire distribution and the speed of responses were slow and the research depended on limited number of companies involved just in Amman city in Jordan. The future works have to expand the population of the study and research other factors might be effect on operation excellence in Jordanian companies.

\section{Acknowledgement}

We would like to thank all colleagues at Jordanian universities and our university Al-Balqa Applied University for their help to develop study instrument and we would like to thank the research companies for their cooperation.

\section{References}

Al Haraisa, Y. E. (2017). Just-In-Time system and its impact on operational excellence: An empirical study on Jordanian industrial companies. International Journal of Business and Management, 12(12), p158.

Armstrong, G. \& Barron, O. (2002). Strategic Thinking and the New Science: Planning in the Midst of Chaos Complexity and Change. New York: Free Press.

Cesarotti, V., \& Spada, C. (2009). A systemic approach to achieve operational excellence in hotel services. International Journal of Quality and Service Sciences, 1(1), 51-56.

Cognizant. (2011). Operational excellence in process industries: Cognizant (NASDAQ: CTSH).

Decker, P. (2005). Developing best practices: How to achieve operational excellence for information services. Quantum2 Coach Thomson Dialog.

Eriksson, P., Pettersson, A., \& Shokatloo, S. (2012). Assessment of leadership aspects that contribute to Operational Excellence: A case study of two large companies in Sweden.

Floyd, S., \& Wolf, C. (2010). Technology Strategy. Encyclopedia of Technology and Innovation Management, 1(1), 125128.

Hair, J. F., Ringle, C. M., \& Sarstedt, M. (2011). PLS-SEM: Indeed, a silver bullet. Journal of Marketing theory and Practice, $19(2), 139-152$.

Henderson, J., \& Venkatraman, N. (1993). Strategic alignment: Leveraging information technology for transforming organizations. IBM Systems Journal, 32(1), 4-16.

Henderson, J. C., \& Venkatraman, H. (1999). Strategic alignment: Leveraging information technology for transforming organizations. IBM Systems Journal, 38(2.3), 472-484.

Jovane, F., Yoshikawa, H., Alting, L., Boer, C. R., Westkamper, E., Williams, D., ... \& Paci, A. M. (2008). The incoming global technological and industrial revolution towards competitive sustainable manufacturing. CIRP annals, 57(2), 641659.

Kalkan, A., Erdil, O., \&Çetinkaya, Ö. (2011). The relationships between firm size, prospector strategy, architecture of information technology and firm performance. Procedia Social and Behavioral Sciences, 24, 854-869.

Lewis, I. (2008). The quantum skills model in management: a new paradigm to enhance effective leadership. Leadership and Organizational Development Journal, 22(6), 264-273.

Lu, D., Betts, A., \& Croom, S. (2011). Re-investigating business excellence: Values, measures and a framework. Total Quality Management \& Business Excellence, 22(12), 1263-1276.

Luftman, J.N. (2000). Assessing business-IT alignment maturity. Communications of Association for Information Systems, $4(14), 1-51$. 
Luftman, J.N., Lewis, P.R., \& Oldach, S.H. (1993). Transforming the enterprise: The alignment of business and information strategies. IBM System Journal, 32(1), $198-221$.

Luftman, J.N., Dorociak, J., Kempaiah, R., \& Rigon, E.H. (2008). Americas Conference on Information Systems, Association for Information Systems.

Maduenyi, S., Oke, A. O., Fadeyi, O. \& Ajagbe, A. M. (2015). Impact of Organizational Structure on Organizational Performance. In the Proceedings of the Covenant University International Conference on African Development Issues (CUICADI 2015) held on 11-13th May, 2015, pp. 354-358.

Năftănăilă, I., Radu, C., \& Cioană, G. (2013). Operational excellence-A key to world-class business performance. Studies in Business and Economics, 8(3), 133-140.

Ojha, S. K. (2015). Operational excellence for sustainability of Nepalese industries. Procedia-Social and Behavioral Sciences, 189, 458-464.

Papp, R. (Ed.). (2001). Strategic information technology: opportunities for competitive advantage. IGI Global.

Parnell, J. A., Lester, D. L., Long, Z., \& Köseoglu, M. A. (2012). How environmental uncertainty affects the link between business strategy and performance in SMEs. Management Decision, 50(4), 546-568.

Peppard, J., \& Campbell, B. (2014). The co-evolution of business/information systems strategic alignment: an exploratory study. Journal of Information Technology. Special Issue "Strategic IT Alignment: Twenty-Five Years On.

Porter, M. (2005). Michael Porter on Strategy. Leadership Excellence, 22, 14.

Porter, M. E., \& Kramer, M. R. (2002). The competitive advantage of corporate philanthropy. Harvard Business Review, $80(12), 56-68$.

Russell, R.H. (2009). Operational excellence: The new lever for profitability and competitive advantage. A Palladium Group White Paper.

Schneider, M. (2003). Operational Excellence. Cengage Learning.

Serfontein, J. J. (2010). The impact of strategic leadership on the operational strategy and performance of business organizations in South Africa (Doctoral dissertation, Stellenbosch: University of Stellenbosch.

Smaczny, T. (2001). Is an alignment between business and information technology the appropriate paradigm to manage IT in today's organizations". Management Decision, 39(10), 797-802.

Symons, C. (2005). IT governance framework. FOrrester Research.

Van Assen, M. F. (2011). Operational Excellence for Services. Center of Operational Excellence.

Venkatraman, N. (1989). The concept of fit in strategy research: Toward verbal and statistical correspondence. Academy of Management Review, 14(3), 423-444.

Wagner, H. T. (2014). Evolvement of business-IT alignment over time: A situated change perspective. Proceedings of the 47th Annual Hawaii International Conference on System Sciences. Honolulu, HI, (pp. 4366-4375).

Wahab, M. H. A. A. A., Ismail, M., \& Muhayiddin, M. N. (2016). Factors Influencing the Operational Excellence of Small and Medium Enterprise in Malaysia. International Journal of Academic Research in Business and Social Sciences, 6(12), 2222-6990.

Waruhiu, H. (2014). Rebalancing the Balanced Scorecard: a sequel to Kaplan and Norton. European Journal of Business and Management, 6(29), 116-124.

Weill, P., \& Broadbent, M. (1998). Leveraging the New Infrastructure. Harvard Business School Press.

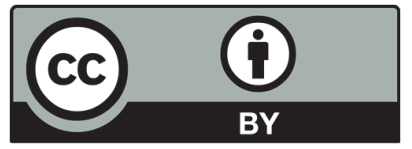

(C) 2021 by the authors; licensee Growing Science, Canada. This is an open access article distributed under the terms and conditions of the Creative Commons Attribution (CC-BY) license (http://creativecommons.org/licenses/by/4.0/). 